Fetal Diagnosis and Therapy
Fetal Diagn Ther 2011;29:238-247

DOI: $\underline{10.1159 / 000322212}$
Received: June 28, 2010

Accepted after revision: October 20, 2010

Published online: January 4, 2011

\title{
Prenatal Diagnosis of Skeletal Dysplasias: Contribution of Three-Dimensional Computed Tomography
}

\author{
Marina Ulla ${ }^{a}$ Horacio Aiello ${ }^{b}$ María Paz Cobos ${ }^{a}$ lêda Oriolie \\ Ricardo García-Mónaco ${ }^{a}$ Adolfo Etchegaray ${ }^{c}$ María Laura Igarzábal ${ }^{d}$ \\ Lucas Otaño ${ }^{b}$ \\ ${ }^{a}$ Department of Radiology, Hospital Italiano de Buenos Aires, Universidad de Buenos Aires, ${ }^{b}$ Department of \\ Obstetrics, Fetal Medicine Unit, Hospital Italiano de Buenos Aires, Instituto Universitario Hospital Italiano, \\ Universidad de Buenos Aires, ' $F e t a l$ Medicine Unit, Hospital Universitario Austral, and ${ }^{\mathrm{d}}$ Genetic Section, \\ Department of Gynecology and Obstetrics, CEMIC Instituto Universitario, Buenos Aires, Argentina; \\ eDepartamento de Genética, Universidade de Rio de Janeiro, Rio de Janeiro, Brasil
}

\section{Key Words}

Skeletal dysplasias - Prenatal diagnosis - Three-dimensional computed tomography - Osteogenesis imperfecta • Chondrodysplasia punctata $\cdot$ Thanatophoric dysplasia

\begin{abstract}
Objective: To describe the contribution of 3-dimensional computed tomography (3D-CT) in the prenatal diagnosis of skeletal dysplasias (SD) in a cohort of patients with inconclusive diagnosis by ultrasound (US). Methods: Between May 2007 and February 2010, six pregnant women with suspected fetal SD on US examination but with no specific diagnosis were studied with 3D-CT. The images were evaluated by a multidisciplinary team who proposed a likely diagnosis. Further postnatal workup included clinical and radiological evaluation in all cases. Prenatal and postnatal diagnoses were compared. Results: The use of 3D-CT provided a precise diagnosis confirmed postnatally in $5 / 6$ patients. These included osteogenesis imperfecta type II $(n=2)$, osteogenesis imperfecta type III $(n=1)$, chondrodysplasia punctata $(n=1)$ and thanatophoric dysplasia type I $(n=1)$. A precise diagnosis could not be made in 1 case - either pre- or post-
\end{abstract}

natally. Conclusion: Prenatal 3D-CT contributed to the diagnosis of the specific fetal SD in the majority of these cases. 3D-CT may have a complementary role to US where fetal SD is suspected, but no specific diagnosis can be made using US alone. Further studies on clinical performance and risk-benefit analysis are needed.

Copyright $\odot 2011$ S. Karger AG, Basel

\section{Introduction}

Osteochondrodysplasias or skeletal dysplasias (SD) are a genetically heterogeneous group of disorders affecting the development of chondro-osseous tissues and leading to abnormalities in the size and shape of various segments of the skeleton [1]. The internationally recognized classification system currently places 372 different conditions into 37 groups defined by molecular, biochemical and/or radiographic criteria [2]. Although pathogenic and molecular criteria have been integrated for classification purposes, SD are still identified by clinical features and imaging appearance.

\section{KARGER}

Fax +4161306 1234

E-Mail karger@karger.ch

www.karger.com (c) 2011 S. Karger AG, Basel

$1015-3837 / 11 / 0293-0238 \$ 38.00 / 0$

Accessible online at:

www.karger.com/fdt
Marina Ulla

Department of Radiology, Hospital Italiano de Buenos Aires

Gascón 450

Buenos Aires 1131 (Argentina)

Tel./Fax +54 114959 0453, E-Mail marina.ulla@ hospitalitaliano.org.ar 
Although individual skeletal disorders are rare, collectively the prevalence of SD recognized at birth likely ranges between 2.3 and 3.2/10,000 births [3], and they account for a significant number of newborns with genetic disorders [4]. The Latin-American Collaborative Study of Congenital Malformations database (live and stillbirths) reported that the most common SD at birth were achondroplasia ( 0.5 and 1.5/10,000 births), thanatophoric dysplasia and achondrogenesis (0.2-0.5/10,000 births), and osteogenesis imperfecta $(0.4 / 10,000$ births) [4]. During pregnancy, the most commonly defined SD were osteogenesis imperfecta type II, thanatophoric dysplasia and achondrogenesis type II, accounting for almost $40 \%$ of the 2,000 prenatal cases reported to the International Skeletal Dysplasia Registry [5]. Precise prenatal diagnosis of the specific SD allows accurate counseling with respect to perinatal lethality, consideration for focused molecular analysis, prediction of neonatal complications, recurrence risk and maternal management [5].

The fetal skeleton is relatively well visualized by ultrasound (US) during the routine morphology scan so that SD with prenatal onset, especially those severe disorders with pronounced shortening of long bones, are often suspected. However, given the large variety and complexity of these anomalies, antenatal diagnosis of the specific disorder remains difficult [6-8]. Although the potential advantages of 3-dimensional ultrasound (3D-US) over 2-dimensional ultrasound (2D-US) have been postulated, neither performs as effectively as postnatal radiological evaluation [9]. It has previously been proposed that 3-dimensional computed tomography (3D-CT) may complement US in the prenatal diagnosis of SD [10-12].

We describe the contribution of $3 \mathrm{D}-\mathrm{CT}$ to the prenatal diagnosis of SD in a cohort of patients where US had not definitely defined the disorder concerned.

\section{Subjects and Methods}

Between May 2007 and February 2010, six pregnant women were referred to our Fetal Medicine Unit with suspected fetal SD. The US findings for each pregnancy were reviewed and discussed by a multidisciplinary team, but no definitive diagnosis could be reached. All women were offered and consented to a fetal 3D-CT examination in an attempt to reach a formal diagnosis. This included counseling about the potential biological risk related to exposure to ionizing radiation.

For the first case, image acquisition was done at 32 weeks of gestation and carried out using a single-detector CT scanner (Secura, Philips) with the following parameters: $40 \mathrm{mAs}, 120 \mathrm{KV}, 1$ pitch and $2 \mathrm{~mm}$ slice thickness. For the remaining cases, image acquisition was done between 30 and 34 weeks of gestation and

Skeletal Dysplasias: Contribution of 3D-CT carried out using a 64-multidetector CT scanner (Aquilion, Toshiba) with the following parameters: $40 \mathrm{mAs}, 100 \mathrm{KV}, 0.75$ pitch and $0.5 \mathrm{~mm}$ slice thickness. This corresponded to a mean irradiation dose given to the fetus of $3.12 \mathrm{mGy}$ which was automatically calculated and displayed on the control panel of the CT scanner. Image acquisition took $15 \mathrm{~s}$ for the first case and $5 \mathrm{~s}$ for remaining cases and these were synchronized with periods of maternal apnea to reduce kinetic artifacts that could mimic fractures or bone deformations. A total of 350-500 images/fetus were stored for further analysis.

CT volume data were transferred to a workstation (Vitrea, Vital Images, Minnetonka, Minn., USA). Postprocessing techniques, including multiplanar reformation, maximum intensity projection (MIP) and volume rendering (3D), with removal of maternal pelvic bones, were performed with dedicated software. The whole postprocessing analysis took nearly $40 \mathrm{~min} / \mathrm{case}$. 3D-CT images were evaluated by an interdisciplinary team consisting of radiologists, specialists in fetal medicine and clinical geneticists who were also aware of the US findings. The findings were also discussed with a specialist in SD (I.O.). All pregnancies were managed expectantly to delivery. Postnatal workup included clinical and radiological evaluation in all cases and a formal postmortem analysis of postmortem examination in case 3.

\section{Results}

Prenatal images are shown in figure 1 , and the suspected diagnoses and postnatal findings are described in table 1.

\section{Case 1}

Referred at 22 weeks' gestation with shortening of long bones and bilateral bowing of the femur, tibia and fibula. The 3D-CT showed that bowing of long bones was due to fractures (bone callus) with normal appearance of the spine and thin ribs. Wormian bones were noted. A diagnosis of osteogenesis imperfecta type III was made. All findings were confirmed at birth, and blue sclera were also observed. A definitive postnatal diagnosis of osteogenesis imperfecta type III was recorded (fig. 2).

\section{Case 2}

Referred at 19 weeks' gestation with rhizomelic shortening and bowing of long bones, frontal bossing and talipes. Additional findings detected by $3 \mathrm{D}-\mathrm{CT}$ were fracture of long bones and ribs. The spine had a normal appearance. Pre- and postnatal diagnoses of osteogenesis imperfecta type IIB were made (fig. 3, 4).

\section{Case 3}

Referred at 20 weeks' gestation with short long bones, intrauterine growth restriction, a narrow thorax, postaxial polydactyly, talipes and female genitalia. In addi- 
Table 1. Results of prenatal imaging techniques and postnatal findings in 6 cases with suspected SD

\begin{tabular}{|c|c|c|c|c|c|}
\hline \multirow{2}{*}{$\begin{array}{l}\text { Case } \\
\text { No. }\end{array}$} & \multirow{2}{*}{$\frac{\text { Prenatal US }}{\text { findings }}$} & \multicolumn{2}{|l|}{ Prenatal 3D-CT } & \multicolumn{2}{|l|}{ Postnatal diagnosis } \\
\hline & & additional findings & diagnosis & findings & diagnosis \\
\hline 1 & $\begin{array}{l}\text { Shortening and bowing of } \\
\text { long bones }\end{array}$ & $\begin{array}{l}\text { Fractures of long bones } \\
\text { Wormian bones }\end{array}$ & $\begin{array}{l}\text { Osteogenesis } \\
\text { imperfecta } \\
\text { type III }\end{array}$ & $\begin{array}{l}\text { Blue sclera } \\
\text { Short long bones } \\
\text { Bowing of long bones } \\
\text { Wormian bones } \\
\text { Length at birth: } 43 \mathrm{~cm} \text { (3rd centile) }\end{array}$ & $\begin{array}{l}\text { Osteogenesis } \\
\text { imperfecta } \\
\text { type III }\end{array}$ \\
\hline 2 & $\begin{array}{l}\text { Rhizomelic shortening of } \\
\text { long bones } \\
\text { Bowing of long bones } \\
\text { Frontal bossing } \\
\text { Club feet }\end{array}$ & $\begin{array}{l}\text { Fracture of long bones } \\
\text { Rib fractures } \\
\text { Decreased bone minerali-zation }\end{array}$ & $\begin{array}{l}\text { Osteogenesis } \\
\text { imperfecta } \\
\text { type II }\end{array}$ & $\begin{array}{l}\text { Blue sclera } \\
\text { Rhizomelic shortening of long bones } \\
\text { Bowing of long bones } \\
\text { Frontal bossing } \\
\text { Club feet } \\
\text { Rib fractures } \\
\text { Length at birth: } 40 \mathrm{~cm} \text { (3rd centile) }\end{array}$ & $\begin{array}{l}\text { Osteogenesis } \\
\text { imperfecta } \\
\text { type IIB }{ }^{1} \\
\text { (day } 18 \text { ) }\end{array}$ \\
\hline 3 & $\begin{array}{l}\text { Short long bones } \\
\text { IUGR } \\
\text { Narrow thorax } \\
\text { Postaxial polydactyly } \\
\text { Club feet } \\
\text { Female genitalia } \\
\text { (karyotype } 46, \mathrm{XY} \text { ) }\end{array}$ & $\begin{array}{l}11 \text { pairs of ribs } \\
\text { Pelvic malformation } \\
\text { Platyspondyly } \\
\text { Increased intervertebral lumbar } \\
\text { space }\end{array}$ & $\begin{array}{l}\text { Campomelic } \\
\text { dysplasia }\end{array}$ & $\begin{array}{l}\text { Short long bones } \\
\text { IUGR } \\
\text { Narrow thorax } \\
\text { Postaxial polydactyly } \\
11 \text { pairs of ribs } \\
\text { Pelvic malformation } \\
\text { Platyspondyly } \\
\text { Increased intervertebral lumbar space } \\
\text { Club feet } \\
\text { Ambiguous genitalia } \\
\text { Micrognathia }\end{array}$ & $\begin{array}{l}\text { No diagnosis }{ }^{1} \\
\text { (day } 1 \text { ) }\end{array}$ \\
\hline 4 & $\begin{array}{l}\text { Increased nuchal translucency } \\
\text { Shortening and bowing of } \\
\text { long bones } \\
\text { Hypoplastic nasal bones }\end{array}$ & $\begin{array}{l}\text { Rhizomelic shortening of } \\
\text { long bones } \\
\text { Decreased bone minerali-zation } \\
\text { Rib fractures }\end{array}$ & $\begin{array}{l}\text { Osteogenesis } \\
\text { imperfecta } \\
\text { type II }\end{array}$ & $\begin{array}{l}\text { Blue sclera } \\
\text { Short long bones } \\
\text { Bowing of long bones } \\
\text { Decreased bone mineralization } \\
\text { Rib fractures } \\
\text { Decreased joint range of motion } \\
\text { Narrow thorax }\end{array}$ & $\begin{array}{l}\text { Osteogenesis } \\
\text { imperfecta } \\
\text { type II }\end{array}$ \\
\hline 5 & $\begin{array}{l}\text { Rhizomelic shortening of } \\
\text { long bones } \\
\text { Epiphyseal calcifications } \\
\text { Malformation of vertebral } \\
\text { bodies }\end{array}$ & $\begin{array}{l}\text { Bowing of long bones } \\
\text { Scoliosis } \\
\text { Inferior maxilla asymmetry } \\
\text { Club feet } \\
\text { Distal phalangeal hypoplasia }\end{array}$ & $\begin{array}{l}\text { Chondro- } \\
\text { dysplasia } \\
\text { punctata, } \\
\text { rhizomelic } \\
\text { type }\end{array}$ & $\begin{array}{l}\text { Rhizomelic shortening of long bones } \\
\text { Epiphyseal calcifications } \\
\text { Malformation of vertebral bodies } \\
\text { Scoliosis } \\
\text { Club feet } \\
\text { Distal phalangeal hypoplasia } \\
\text { Inferior maxilla asymmetry }\end{array}$ & $\begin{array}{l}\text { Chondro- } \\
\text { dysplasia } \\
\text { punctata, } \\
\text { rhizomelic } \\
\text { type }\end{array}$ \\
\hline 6 & $\begin{array}{l}\text { Short long bones } \\
\text { Brachycephaly } \\
\text { Megalencephaly } \\
\text { Short ribs } \\
\text { Narrow thorax }\end{array}$ & $\begin{array}{l}\text { Bowing of long bones } \\
\text { Frontal bossing } \\
\text { Platyspondyly }\end{array}$ & $\begin{array}{l}\text { Thanato- } \\
\text { phoric } \\
\text { dysplasia } \\
\text { type I }\end{array}$ & $\begin{array}{l}\text { Short long bones } \\
\text { Bowing of long bones } \\
\text { Brachycephaly } \\
\text { Megalencephaly } \\
\text { Facial dysmorphy } \\
\text { Frontal bossing } \\
\text { Short ribs } \\
\text { Narrow thorax }\end{array}$ & $\begin{array}{l}\text { Thanato- } \\
\text { phoric } \\
\text { dysplasia }^{1} \\
\text { ( } 2 \text { h after } \\
\text { birth) }\end{array}$ \\
\hline
\end{tabular}

IUGR $=$ Intrauterine growth restriction. ${ }^{1}$ Neonatal death.

tion, 3D-CT showed 11 pairs of ribs, a pelvic malformation, platyspondyly and increased intervertebral lumbar space. No diagnosis was made prenatally, and this remained the case even after autopsy. The parents declined further molecular testing.

\section{Case 4}

Referred at 22 weeks' gestation with a history of increased nuchal translucency, rhizomelic shortening and bowing of long bones and hypoplastic nasal bones. In addition, 3D-CT detected rib fractures, leading to a prena- 

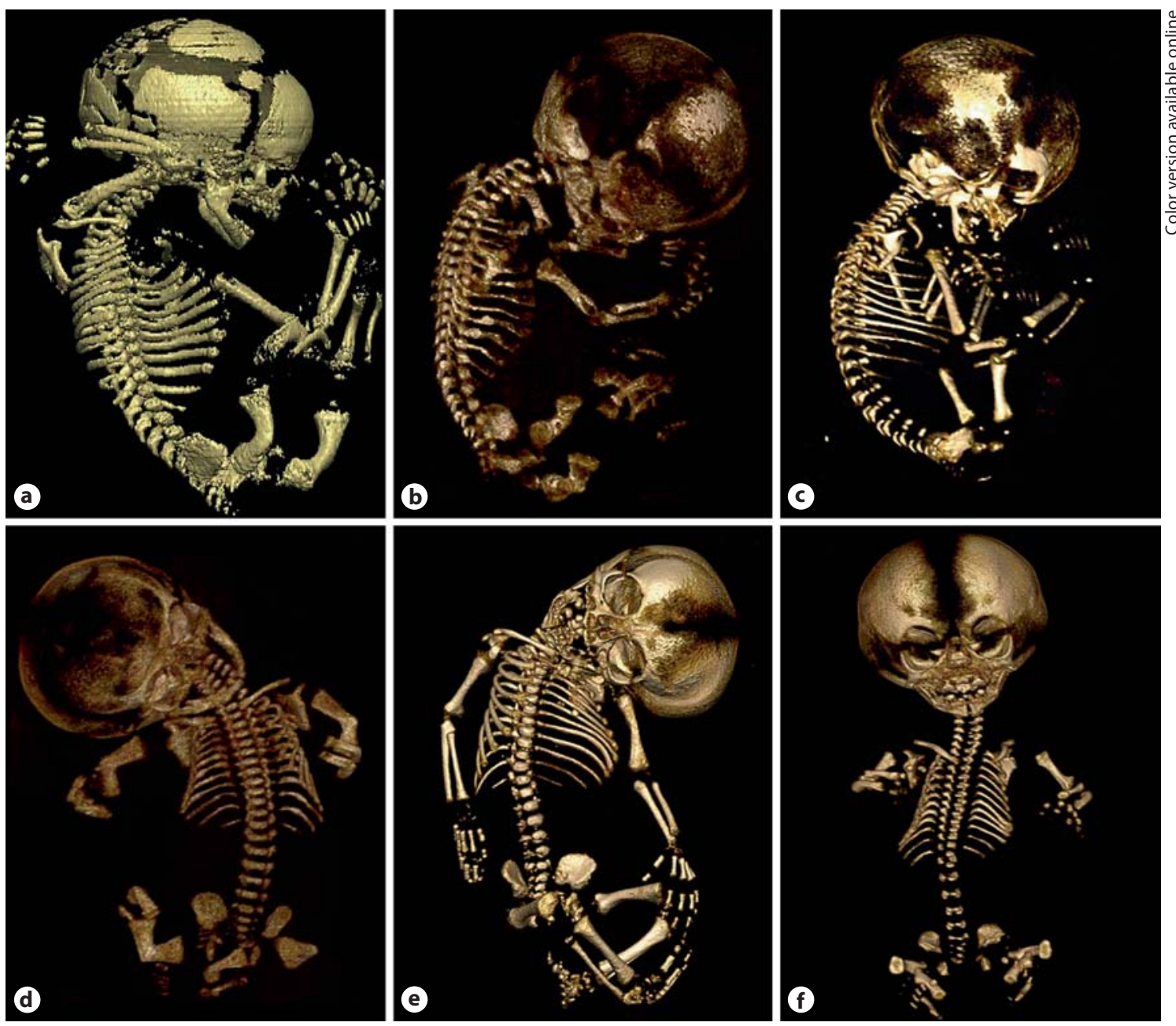

Fig. 1. Prenatal 3D-CT reconstructions of the entire fetus. a Case 1. b Case 2. c Case 3. d Case 4. e Case 5. f Case 6 .

tal diagnosis of osteogenesis imperfecta type II, confirmed postnatally (fig. 5, 6).

\section{Case 5}

Referred at 23 weeks' gestation with rhizomelic shortening of long bones, epiphyseal calcifications and malformation of vertebral bodies. 3D-CT also showed bowing of long bones, scoliosis, inferior maxilla asymmetry, talipes and distal phalangeal hypoplasia. A diagnosis of the rhizomelic type of chondrodysplasia punctata was made both pre- and postnatally (fig. 7).

\section{Case 6}

Referred at 22 weeks' gestation with shortening and bowing of long bones, brachycephaly, megalencephaly, short ribs and a narrow thorax. The 3D-CT also revealed platyspondyly, a small foramen magnum, a short base of the skull, cupped spur-like irregular flaring of metaphyses, a lack of caudal widening of the spinal canal and a square/short pelvis with a small sciatic notch and medial spurs. A diagnosis of thanatophoric dysplasia type I was made prenatally and confirmed after birth (fig. 8).

3D-CT contributed to a precise diagnosis, confirmed postnatally, in $5 / 6$ patients. In the only case where $3 \mathrm{D}-\mathrm{CT}$ did not enable prenatal diagnosis, no formal postnatal diagnosis could be reached.

\section{Discussion}

In this cohort, 3D-CT contributed to a precise prenatal diagnosis in 5/6 cases where an SD had been suspected, but no formal US-based diagnosis could be reached. The only case in which a specific diagnosis could not be rec- 
Fig. 2. Case 1: osteogenesis imperfecta type III. a Prenatal 2D-US. $\mathrm{p}=$ Placenta. b Prenatal 3D-CT: bowing of the femur (arrowhead). c, d Prenatal 3D-CT of the skull depicting the wormian bones (arrowhead).

Fig. 3. Case 2: osteogenesis imperfecta type IIB. $\mathrm{f}=$ Femur; $\mathrm{t}=$ tibia; $\mathrm{fb}=$ fibula. a Prenatal 2D-US. b Prenatal 3D-CT: bowing and shortening of lower limbs and normal lumbar spine (open white arrow). c Newborn with club foot. d Postnatal radiological examination.
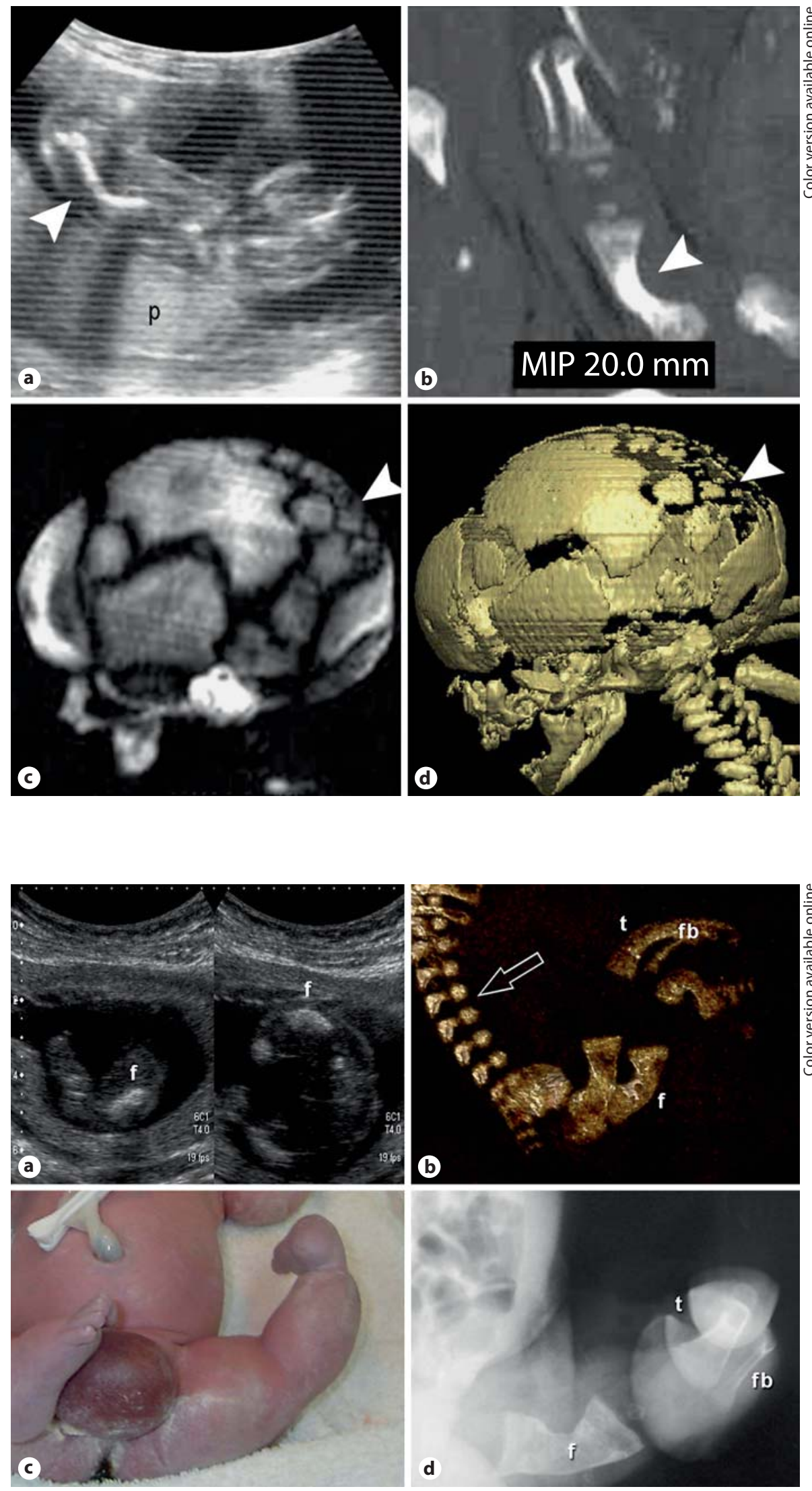

fb

Ulla et al. 
Fig. 4. Case 2: osteogenesis imperfecta type II. a 3D-CT MIP reconstruction of the fetal thorax (sagittal view). $\mathrm{h}=$ Humerus; CS = cervical spine. $\mathbf{b}$ 3D-CT coronal reconstruction of the entire fetus showing multiple irregular ribs with fractures $\left({ }^{*}\right)$. c Postnatal chest X-ray confirming bilateral fractures of ribs $\left({ }^{*}\right)$.

Fig. 5. Case 4: osteogenesis imperfecta type II. Abd = Abdomen; $\mathrm{Tx}=$ thorax; $\mathrm{Ul}=$ upper limb; $\mathrm{e}=$ ear; $\mathrm{h}=$ humerus; $\mathrm{u}=\mathrm{ulna} ; \mathrm{r}=$ radius $\mathrm{f}=$ femur. $\mathbf{a}$ Prenatal 2D-US: narrow thorax. b Prenatal 3D-US: bowing of the right upper limb. c Prenatal 2D-US: bowing of the femur. d Prenatal 3D-CT: shortening and bowing of the upper limb. Note also the humeral fracture $\left(^{*}\right)$.
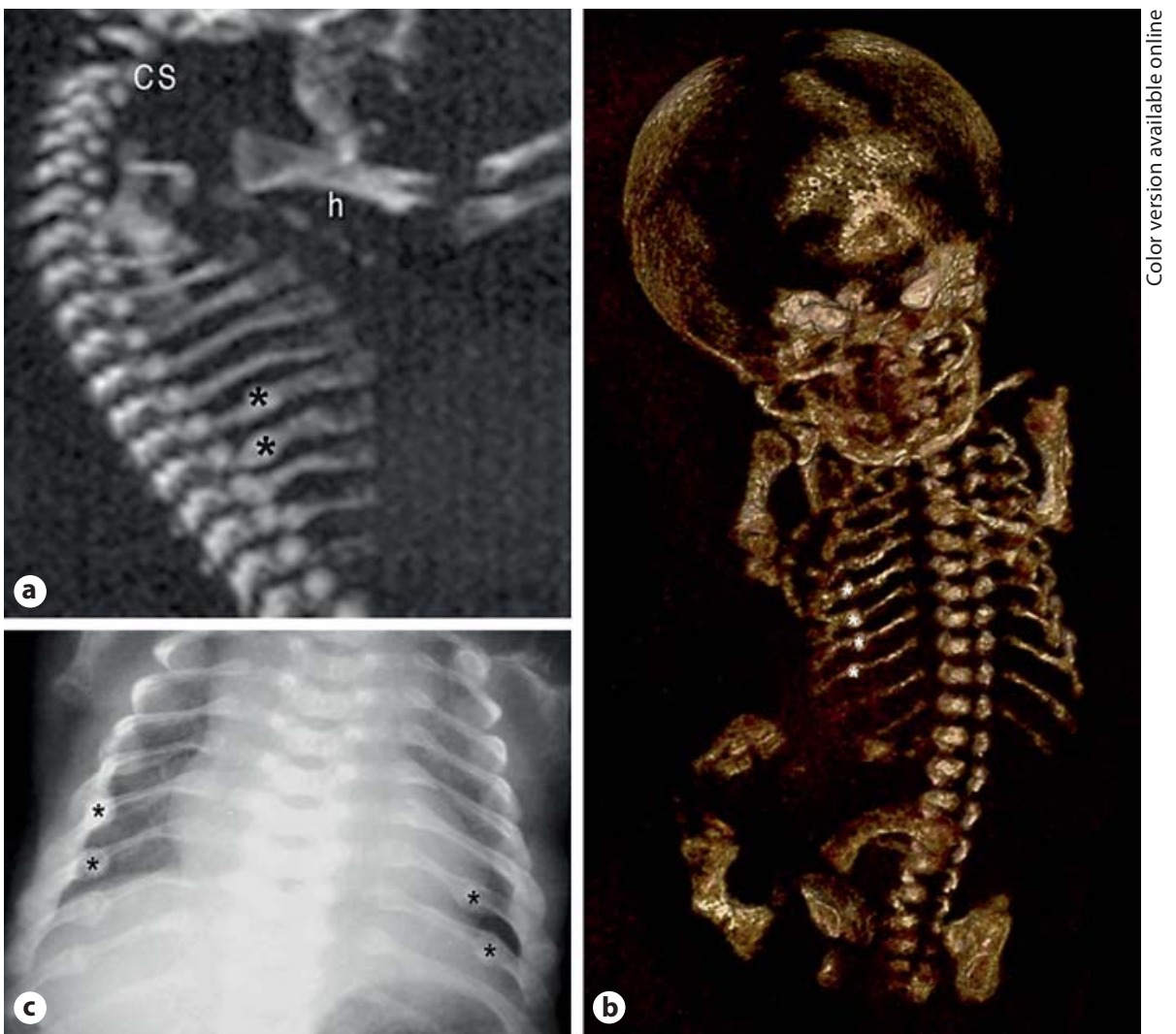

(b)
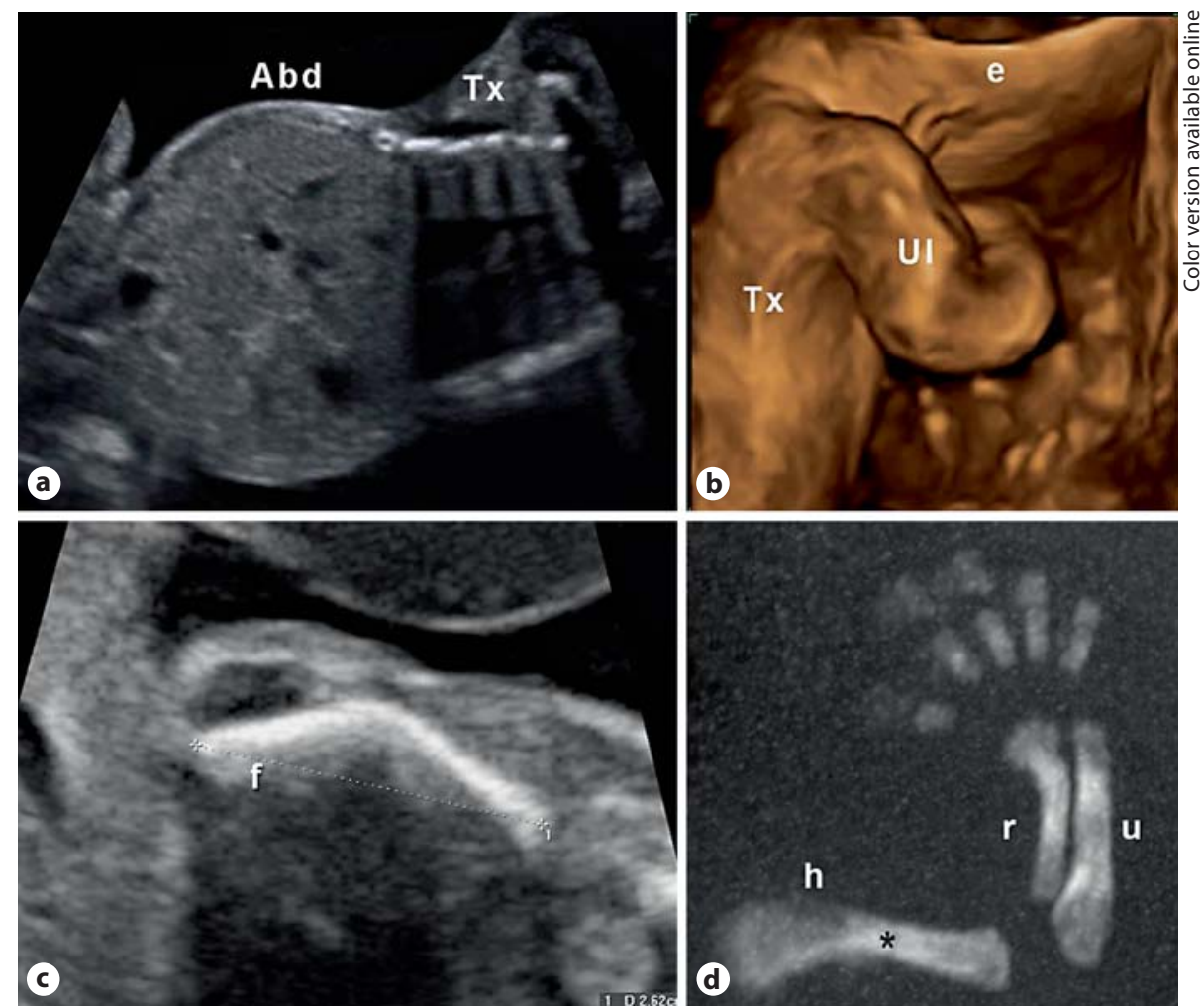

Fetal Diagn Ther 2011;29:238-247 


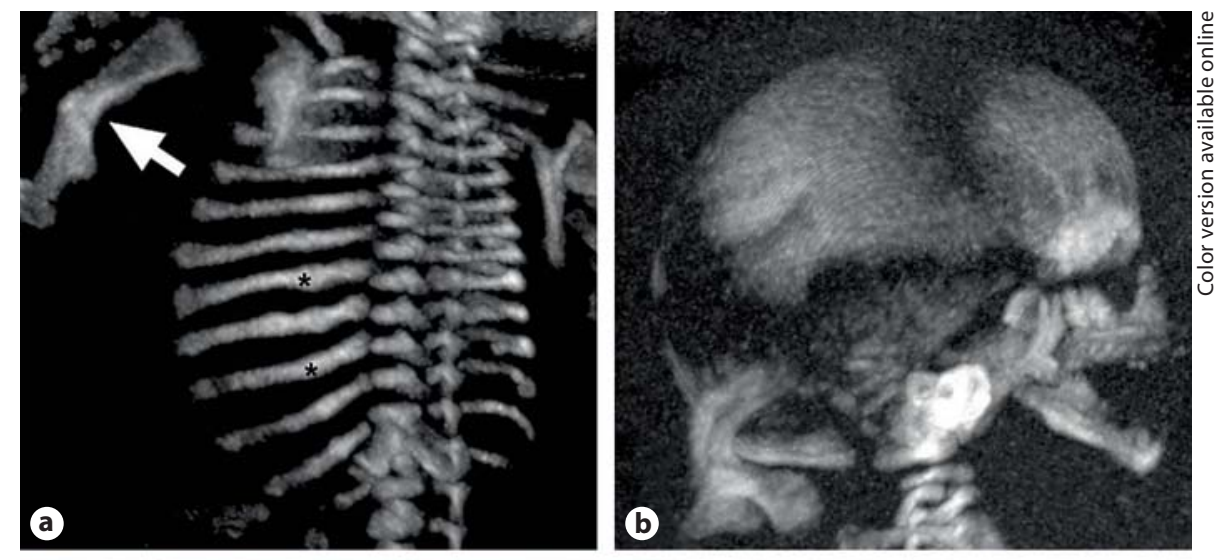

Fig. 6. Case 4: osteogenesis imperfecta type II. a 3D-CT MIP reconstruction of the fetal thorax showing 12 pairs of ribs, some of which are fractured $(*)$. Also note bowed upper limb (arrow). b 3D-CT MIP reconstruction with lateral view of the skull showing decreased bone mineralization. c Picture of the newborn.

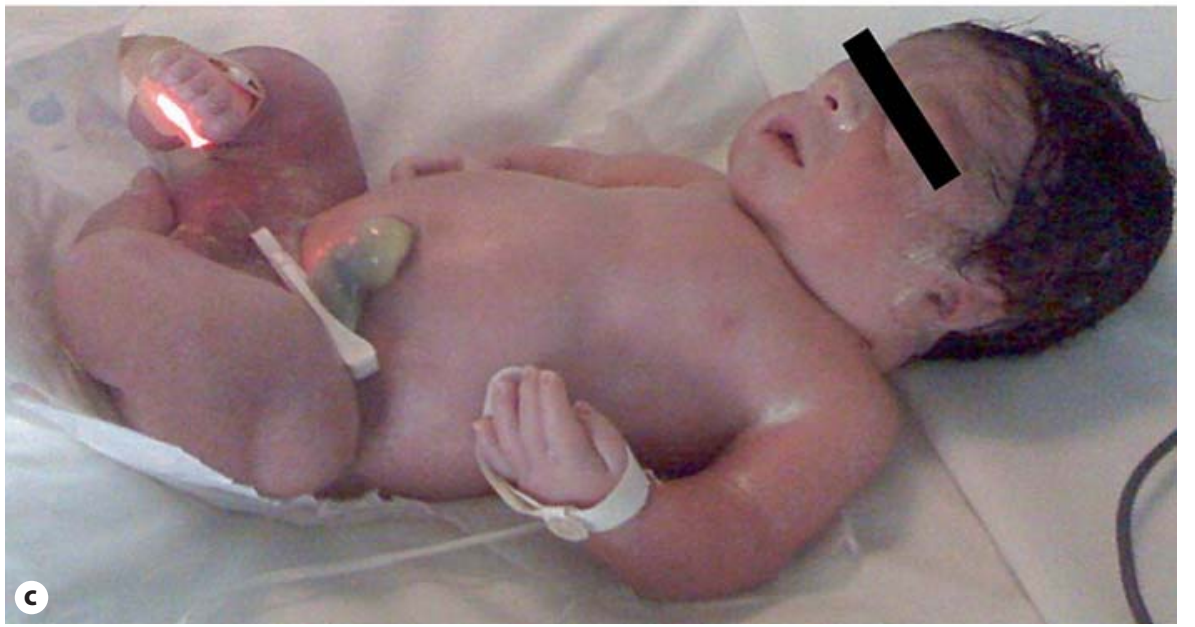

ognized remained inconclusive after full postmortem workup. Images obtained by 3D-CT allowed the visualization of some additional details of the fetal skeleton that were not clearly recognized in the US assessment and that proved crucial for specific diagnosis. 3D-CT was especially effective in confirming/excluding bone fractures, recognizing wormian bones and for detailed evaluation of the fetal spine in respect of vertebral body shape and intervertebral spaces. We also found that the 3D-CT reconstruction allowed visualization of the whole fetal skeleton without contamination from maternal anatomy. The images were astonishingly clear and easily decipherable for experts in SD not familiar with prenatal US.

US is the primary tool for prenatal screening and diagnosis of SD. However, it is not uncommon that whilst an SD is suspected, a precise diagnosis cannot be made. Most SD prenatal series report a diagnostic accuracy $<50 \%$ [6-8, 13-15]. The International Skeletal Dysplasia Registry, reporting a prospective analysis of 405 cases defined by a standardized approach in specialized centers, found that the preliminary US diagnosis was right in $78 \%$ of the cases [5]. That means that in the best hands, the precise diagnosis will be wrong in 1 of 5 cases. Making a specific prenatal diagnosis of SD by US is complicated by a number of factors. Obesity, fetal position and advanced gestational age are known limitations for US diagnosis in general [16]. In addition, SD represent some of the most complex birth defects seen - with a wide variety of rare conditions; so few centers have sufficient experience to differentiate between these disorders. The characteristic sonographic findings of SD differ with advancing gestational age and vary between cases of an individual condition [5]. For example, osteogenesis imperfecta type II may present with a single fracture or with multiple crumpled long bones, and campomelic dysplasia may present without campomelia.

It has been suggested that 3D-US is more sensitive than 2D-US for characterization of SD as it can identify significantly more abnormalities, especially in respect of facial dysmorphism and anomalies of the hands and feet 
Fig. 7. Case 5: chondrodysplasia punctata. a 3D-CT MIP. $\mathbf{b}$ 3D reconstructions of pelvic bones showing sacral body malformation (open arrow) and punctate calcifications in the sacrum, triradiate cartilage, ischium and pubis (white arrows). Notice widening of the symphysis (arrowhead). c MIP reconstruction of pelvis and lower limbs. Rhizomelic shortening of long bones and punctate calcifications on the knee and tarsum (arrows). d MIP reconstruction of a foot shows tarsal calcifications (white arrow) and distal phalangeal hypoplasia (red arrow, online version only).

Fig. 8. Case 6: thanatophoric dysplasia type I. 3D-CT reconstructions. a Telephone-receiver-like femurs, spinal and pelvic malformation. $\mathrm{f}=$ Femur. $\mathbf{b}$ Platyspondyly. c Narrow chest with short ribs. d Characteristic craniofacial appearance (brachycephaly and megalencephaly).
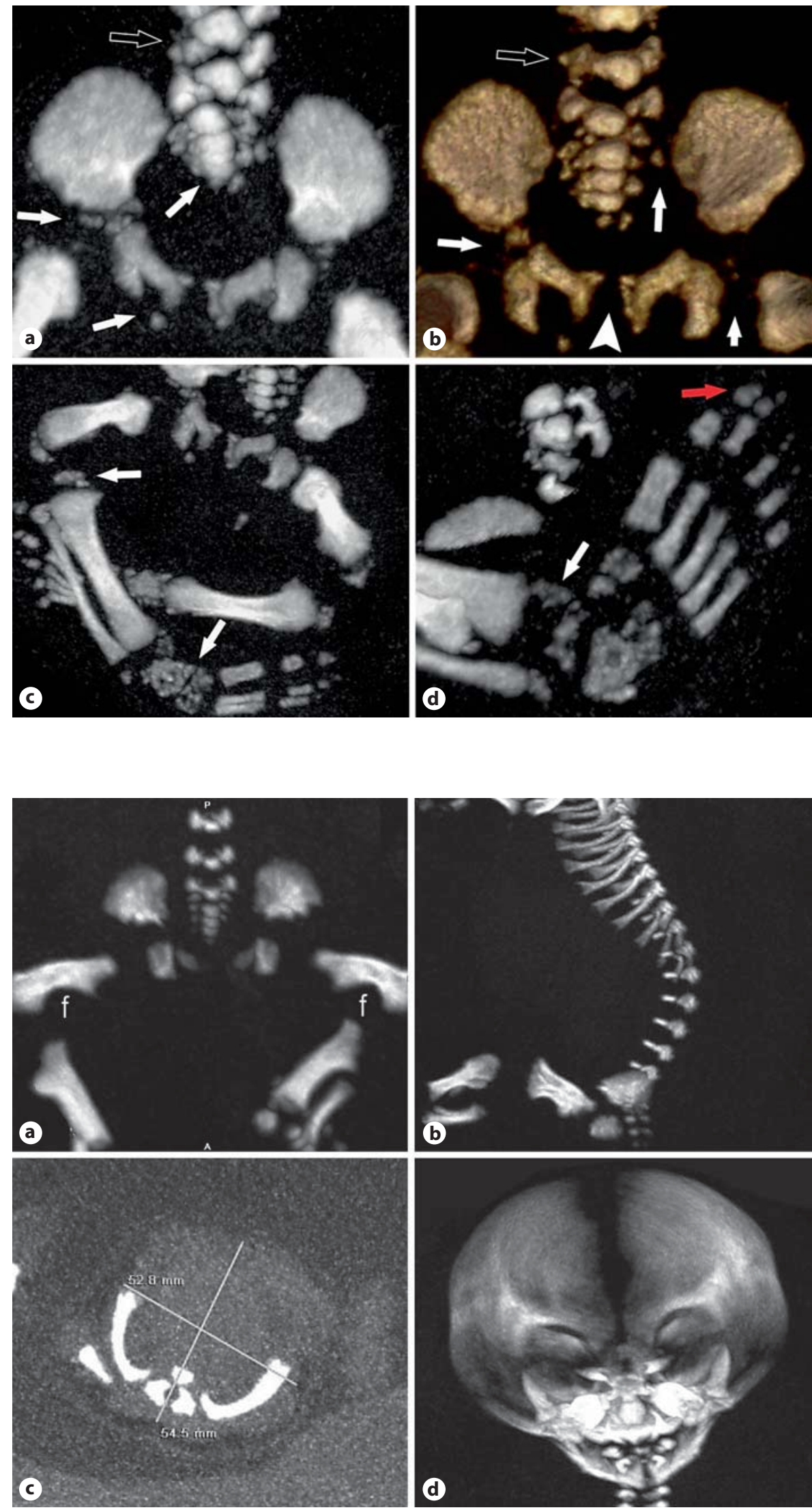
[17-19]. 3D-US is currently accepted as a complementary technique to conventional 2D-US in the prenatal diagnosis of SD $[20,21]$. In our series, the use of 3D-US was limited because it was not available for some cases and there was a lack of experience with the technique. Other groups have reported that $3 \mathrm{D}-\mathrm{CT}$ is more accurate than US for prenatal diagnosis of bone abnormalities [9-13]. In particular 3D-CT appears to be more effective for the evaluation of the skull, ribs, pelvic bones, vertebrae and bone mineralization [9]. In a recent review, Cassart [22] describes the possible role of this technique in the prenatal diagnosis of SD. The author points out that CT images give a precise view of the bone structure (cortical/medullary bone ratio), metaphyseal deformities and possible fractures, and allow the clinician to appreciate global proportions and morphological deformities (e.g. curved bones, short ribs, spinal shortening, luxations). 3D-CT demonstrates skeletal findings that can be overlooked by US such as deformities of the vertebral column, pelvic bones and ossification centers. Notably, Cassart suggests that $3 \mathrm{D}-\mathrm{CT}$ is not currently accurate enough for the analysis of metaphyseal deformities and that US performs better in the assessment of bone density [22].

$3 \mathrm{D}-\mathrm{CT}$ exposes the fetus to ionizing radiation. Theoretically, this is a similar dose ( $3 \mathrm{mGy}$ ) to conventional fetal radiological examination and to that received during CT pelvimetry [23-25]. Radiation exposure is a concern in both adults and children, especially the potential carcinogenic effect of low doses of X-ray radiation for children [26]. Therefore, the risk of irradiation should be carefully balanced against the value of reaching a firm prenatal diagnosis. The 2008 American College of Radiology practice guidelines state that the risk decreases with advancing gestation $[27,28]$. The standard of imaging improves as bone mineralization increases and $3 \mathrm{D}$ reconstruction is easier as the fetus is less mobile - and for this combination of reasons we chose to perform 3DCT during the third trimester [22]. Magnetic resonance provides an alternative method of multiplanar imaging with excellent soft tissue contrast and requires no radiation - but appears to be inferior to US in the evaluation of fetal bones $[29,30]$. We note that research is focusing on new bone echoplanar imaging sequences designed to delineate bony structures that may provide a better standard of imaging with this modality [31, 32].

Whilst advances in molecular genetics have recently improved our ability to reach a firm diagnosis for many $\mathrm{SD}$, this tool is not routinely available in our clinical setting. In many centers, diagnostic accuracy is dependent on defining the pattern of a constellation of clinical abnormalities [5]. We suggest that 3D-CT provides a useful adjunct to $2 \mathrm{D} / 3 \mathrm{D}$-US and is likely to have an impact on clinical management, particularly in situations where molecular testing is not readily available.

In conclusion, 3D-CT may have a complementary role to US in selected cases of suspected fetal SD in which a specific diagnosis or a precise prognosis cannot be achieved by US alone. Further studies on clinical performance and risk-benefit analysis are needed.

\section{References}

1 Gonçalves LF, Kusanovic JP, Gotsch F, Espinoza J, Romero R: The fetal musculoskeletal system; in Callen PW (ed): Ultrasonography in Obstetrics and Gynecology, ed 5. Philadelphia, Saunders Elsevier, 2008, pp 419-492.

-2 Superti-Furga A, Unger S: Nosology and classification of genetic skeletal disorders: 2006 revision. Am J Med Genet A 2007;143: $1-18$.

3 Stoll C, Dott B, Roth MP, Alembik Y: Birth prevalence rates of skeletal dysplasias. Clin Genet 1989;35:88-92.

4 Orioli IM, Castilla EE, Barbosa-Neto JG: The birth prevalence rates for the skeletal dysplasias. J Med Genet 1986;23:328-332.

5 Krakow D, Alanay Y, Rimoin LP, Lin V, Wilcox WR, Lachman RS, Rimoin DL: Evaluation of prenatal-onset osteochondrodysplasias by ultrasonography: a retrospective and prospective analysis. Am J Med Genet A 2008;15:1917-1924.
-6 Sharony R, Browne C, Lachman RS, Rimoin DL: Prenatal diagnosis of the skeletal dysplasias. Am J Obstet Gynecol 1993;169:668-675.

7 Doray B, Favre R, Viville B, Langer B, Dreyfus M, Stoll C: Prenatal sonographic diagnosis of skeletal dysplasias: a report of 47 cases. Ann Genet 2000;43:163-169.

-8 Parilla BV, Leeth EA, Kambich MP, Chilis P, MacGregor SN: Antenatal detection of skeletal dysplasias. J Ultrasound Med 2003;22: 255-258.

9 Ruano R, Molho M, Roume J, Ville Y: Prenatal diagnosis of fetal skeletal dysplasias by combining two-dimensional and threedimensional ultrasound and intrauterine three-dimensional helical computer tomography. Ultrasound Obstet Gynecol 2004;24: 134-140.
10 Cassart M, Massez A, Cos T, Tecco L, Thomas D, Van Regemorter N, Avni F: Contribution of three-dimensional computed tomography in the assessment of fetal skeletal dysplasia. Ultrasound Obstet Gynecol 2007; 29:537-543.

-11 Quarello E, Roume J, Molho M, Gorincour G, Saada J, Simon I, Bernard JP, Ville Y: Twins discordant for fetal skeletal abnormalities: a natural confrontation between the two siblings. Prenat Diagn 2008;28:21-27.

12 Dighe M, Fligner C, Cheng E, Warren B, Dubinsky T: Fetal skeletal dysplasia: an approach to diagnosis with illustrative cases. Radiographics 2008;28:1061-1077.

13 Rasmussen SA, Bieber FR, Benacerraf BR, Lachman RS, Rimoin DL, Holmes LB: Epidemiology of osteochondrodysplasias: changing trends due to advances in prenatal diagnosis. Am J Med Genet 1996;61:49-58. 
14 Gaffney G, Manning N, Boyd PA, Rai V, Gould S, Chamberlain P: Prenatal sonographic diagnosis of skeletal dysplasias - a report of the diagnostic and prognostic accuracy in 35 cases. Prenat Diagn 1998; 18: 357-362.

15 Tretter AE, Saunders RC, Meyers CM, Dungan JS, Grumbach K, Sun CC, Campbell AB, Wulfsberg EA: Antenatal diagnosis of lethal skeletal dysplasias. Am J Med Genet 1998;75: 518-522.

16 Urban BA, Duhl AJ, Ural SH, Blakemore KJ, Fishman EK: Helical CT amniography of congenital diaphragmatic hernia. Am J Roentgenol 1999;172:809-812.

$\checkmark 17$ Garjian KV, Pretorius DH, Budorick NE, Cantrell CJ, Johnson DD, Nelson TR: Fetal skeletal dysplasia: three-dimensional US initial experience. Radiology 2000;214:717723.

18 Kos M, Hafner T, Funduk-Kurjak B, Bozek T, Kurjak A: Limb deformities and three-dimensional ultrasound. J Perinat Med 2002; 30:40-47.

19 Krakow D, Williams J 3rd, Poehl M, Rimoin DL, Platt LD: Use of three-dimensional ultrasound imaging in the diagnosis of prenatal-onset skeletal dysplasias. Ultrasound $\mathrm{Ob}$ stet Gynecol 2003;21:467-472.
20 Viora E, Sciarrone A, Bastonero S, Errante G, Botta G, Campogrande M: Three-dimensional ultrasound evaluation of short-rib polydactyly syndrome type II in the second trimester: a case report. Ultrasound Obstet Gynecol 2002;19:88-91.

21 Steiner H: Potential 3-dimensional (3D) ultrasound in the diagnosis of fetal abnormalities. Gynäkologe 1995;28:315-320.

22 Cassart M: Suspected fetal skeletal malformations or bone diseases: how to explore. Pediatr Radiol 2010;40:1046-1051.

23 Breidt D, Bouquigny F, Clement JP, Menechal P, Levert M, Quereux L, Pierot L: Helical CT pelvimetry: advantages of a low dose volume acquisition technique. J Radiol 2003;84: 1027-1030.

24 Cordoliani YS: Pregnancy and medical radiation: to demystify and take the drama out of managing. J Radiol 2002;83:595-597.

25 Kölble N, Sobetzko D, Ersch J, Stallmach T, Eich G, Huch R, Huch A, Superti-Furga A, Wisser J: Diagnosis of skeletal dysplasia by multidisciplinary assessment: a report of 2 cases of thanatophoric dysplasia. Ultrasound Obstet Gynecol 2002;19:92-98.
26 Brenner DJ, Hall EJ: Computed tomography - an increasing source of radiation exposure. N Engl J Med 2007;357:2277-2284.

-27 Streffer C, International Commission on Radiation Protection: The ICRP 2007 recommendations. Radiat Prot Dosimetry 2007; 127:2-7.

28 American College of Radiology: ACR practice guideline for imaging pregnant or potentially pregnant adolescents and women with ionizing radiation. Reston, American College of Radiology, 2008.

29 Brunelle F: Fetal imaging in a new era. Ultrasound Obstet Gynecol 2001;18:91-95.

30 Blaicher W, Mittermayer C, Messerschmidt A, Deutinger J, Bernaschek G, Prayer D: Fetal skeletal deformities: the diagnostic accuracy of prenatal ultrasonography and fetal magnetic resonance imaging. Ultraschall Med 2004;25:195-199.

31 Brugger PC, Stuhr F, Lindner C, Prayer D: Methods of fetal MR: beyond $\mathrm{T}_{2}$-weighted imaging. Eur J Radiol 2006;57:172-178.

32 Prayer D, Brugger PC: Investigation of normal organ development with fetal MRI. Eur Radiol 2007;17:2458-2471. 